\title{
INVESTIGATION ON THE EMISSION REDUCTION TECHNIQUE IN ACETONE-BIODIESEL ASPIRATED DIESEL ENGINE
}

\author{
ARULPRAKASAJOTHI MAHALINGAM ${ }^{\star}$; DINESH BABU MUNUSWAMY **; YUVARAJAN DEVARAJAN* \\ and SANTHANAKRISHNAN RADHAKRISHNAN ${ }^{\ddagger}$
}

\begin{abstract}
In this work, palm biodiesel was evaluated as an alternative to the petroleum diesel in compression ignition engine. This work would pave the way for the evaluation of the technological feasibility of employing palm biodiesel (BD100) in a diesel engine and also to discover the prospect of running a diesel engine on acetone in the dual-fuel blending mode to view its emission characteristics. Acetone was blended with palm biodiesel and operated at a compression ratio of 16. A base-catalysed transesterification process was employed to convert palm oil into palm biodiesel. Acetone with $96.4 \%$ purity was used as an oxygenated additive. The experimental results have revealed that the acetone to palm biodiesel blends gave a significant reduction in $\mathrm{HC}$ (hydrocarbons), $\mathrm{CO}$ (carbon monoxide), $\mathrm{NO}_{x}$ (nitrogen oxides) and smoke emissions when compared to palm biodiesel under naturally aspirated conditions.
\end{abstract}

\section{Keywords: acetone; palm bio-diesel; blends; emissions.}

Date received: 27 September 2017; Sent for revision: 14 October 2017; Received in final form: 12 January 2018; Accepted: 14 February 2018.

\section{INTRODUCTION}

Diesel engine produces more torque than petroleum engine, and is more fuel efficient (Yuvarajan and Ramanan, 2016a,b). Hence, it is extensively deployed in high power and automobile applications. However, the diesel fuel emits higher emissions of compounds which form a primary source of global dimming, global warming and acid rain. A lower environmental impact and a reduction in air pollution can be achieved by using biofuels. The combustion of biofuels in the engine would reduce smoke, carbon monoxide $(\mathrm{CO})$ and hydrocarbons (HC) emissions. However, biofuels have some drawbacks. These include poor cold flow

\footnotetext{
* Department of Mechanical Engineering,

Vel Tech Rangarajan Dr Sagunthala R\&D Institute of Science and Technology, Chennai, India. E-mail: dyuvarajan2@gmail.com

** Department of Mechanical Engineering, Panimalar Engineering College, Chennai, India.

\# Department of Mechanical Engineering, SRM University, Chennai, India.
}

properties, high viscosity, poor oxidation stability and high nitrogen oxides $\left(\mathrm{NO}_{\mathrm{x}}\right)$ emissions.

Alcohols have been found to be an alternative fuel in view of storage and handling (Yuvarajan $e t$ al., 2017). Many studies have proven that doping alcohols into diesel improves the diesel-properties. Many works have been focused on adding alcohols and biodiesel to diesel. But very few works have been carried out on neat alcohol-biodiesel (Venkata Ramanan and Yuvarajan, 2015a, b; Devarajan et al., 2017; 2016). Dual-fuel blending is an effective technique for reducing the emissions from diesel engines (Radhakrishnan et al., 2017; Santhosham and Aghalayam., 2016; Devarajan et al., 2017a, b). Hence in this work, the author makes the effort to reduce the emissions of neat biodiesel fueled engine by adding acetone to biodiesel as an emulsion. Further, this investigation would pave the way to evaluate the technological feasibility of employing palm biodiesel (BD100) in a diesel engine. It would also help discover the prospect of running a diesel engine on biodiesel/acetone in a dual-fuel technique, and to view its emission characteristics. 


\section{MATERIALS AND REAGENTS}

\section{Palm Biodiesel}

Palm oil was then converted into palm biodiesel by the simple transesterification process which involves potassium hydroxide (catalyst) and methanol (basic alcohol). Palm oil was added to a mixture containing $15 \%$ of methanol and $5 \%$ of potassium hydroxide (catalyst) and stirred for 75 min at $60^{\circ} \mathrm{C}$. The main chemical properties of palm biodiesel (BD100) and diesel are examined as per ASTM norms and are listed in Table 1.

\section{Experimental Set-up}

Experimental trials were carried out on a stationary single cylinder, water-cooled $4.4 \mathrm{~kW}$ variable compression diesel engine. The complete specifications of the tested engine and equipment are detailed in Table 2. AVL Digas 444 flue gas analyser was employed to carry out the emission analysis of the test fuel. $\mathrm{HC}, \mathrm{NO}_{\mathrm{x}}$ and $\mathrm{CO}$ emissions are measured by the analyser.

\section{RESULTS AND DISCUSSION}

\section{Carbon Monoxide}

The variation of the $\mathrm{CO}$ emission with changing loads for tested fuels is shown in Figure 1. (Yilmaz et al., 2016). CO emissions from biofuels are less than diesel at all conditions owing to its oxygenrich nature (Yilmaz et al., 2016). CO emission reduces with increase in acetone content. By adding acetone to palm biodiesel, a significant reduction in $\mathrm{CO}$ emissions, was observed, at all loads when compared to the neat palm biodiesel. The lower CO emission is attributable to the improved combustion rate. Gaseous fuel makes the mixture leaner and promotes combustion (Schroder et al., 2013). CO emissions for BD100, BD100 + Acetone and Diesel are $0.11 \%, 0.09 \%$ and $0.14 \%$ respectively at peak load conditions.

\section{Hydrocarbons}

The variation of the $\mathrm{HC}$ emissions with changing loads for the tested fuels is shown in

TABLE 1. PROPERTIES OF TESTED FUELS

\begin{tabular}{lccc}
\hline Properties & POBD100 & Diesel & Method \\
\hline Water content $(\%)$ & 0.03 & 0.001 & ASTM D2709 \\
Density @ $18^{\circ} \mathrm{C}\left(\mathrm{g} \mathrm{m}^{-3}\right)$ & 0.8833 & 0.8210 & ASTM D4052 \\
Kinematic Viscosity @35 ${ }^{\circ} \mathrm{C}$ & & & \\
$\quad\left(\mathrm{mm}^{2} \mathrm{~s}^{-1}\right)$ & 4.30 & 2.5 & ASTM D445 \\
Calorific value $\left(\mathrm{kJ} \mathrm{kg}^{-1}\right)$ & 38108 & 42950 & ASTM D240 \\
Cetane index $(\mathrm{CI})$ & 52 & 46 & ASTM D976 \\
Flash point in ${ }^{\circ} \mathrm{C}$ & 140 & 50 & ASTM D93 \\
Sulphur content & - & - & - \\
Iodine value $(\mathrm{g} / 100 \mathrm{~g}$ oil sample $)$ & 65 & - & ASTM D1510 \\
$\mathrm{C}(\%)$ & 77.2 & - & ASTM D5291 \\
$\mathrm{H}(\%)$ & 11.4 & - & ASTM D5291 \\
$\mathrm{O}(\%)$ & 11.4 & - & - \\
\hline
\end{tabular}

Note: POBD100 - palm biodiesel.

TABLE 2. SPECIFICATION OF EXPERIMENTAL SET-UP

\begin{tabular}{lc}
\hline Make & Tafe \\
Rated power & $50 \mathrm{hp}$ \\
Cylinder & Three \\
Rated speed & $1500 \mathrm{rpm}$ \\
Bore diameter (D) & $87.5 \mathrm{~mm}$ \\
Stroke (L) & $110 \mathrm{~mm}$ \\
Compression ratio & $17: 1$ \\
Cone angle & $110^{\circ}$ \\
Injection type & Direct injection \\
Fuel injection pressure & $200-1400 \mathrm{bar}$ \\
Injection timing & $23^{\circ} \mathrm{bTDC}$ \\
\hline
\end{tabular}

Figure 2. HC emissions from biofuels are less than diesel at all conditions owing to its oxygen-rich nature (Yilmaz et al., 2016; Yuvarajan et al., 2017). $\mathrm{HC}$ emission increases with load for all the tested fuels. At the higher load, the mixture is too rich to deliver the power resulting in higher $\mathrm{HC}$ emission. $\mathrm{HC}$ emission reduces with increase in the acetone content. By adding acetone to palm biodiesel resulted in a significant reduction in HC emissions, at all loads when compared to neat palm biodiesel. The lower $\mathrm{HC}$ emission is attributable to the improved combustion rate. Acetone makes the mixture leaner and promotes combustion (Schroder et al., 2013). HC emissions for BD100, BD100 + Acetone and Diesel are 69,65 and $71 \mathrm{ppm}$ respectively at peak load conditions. 


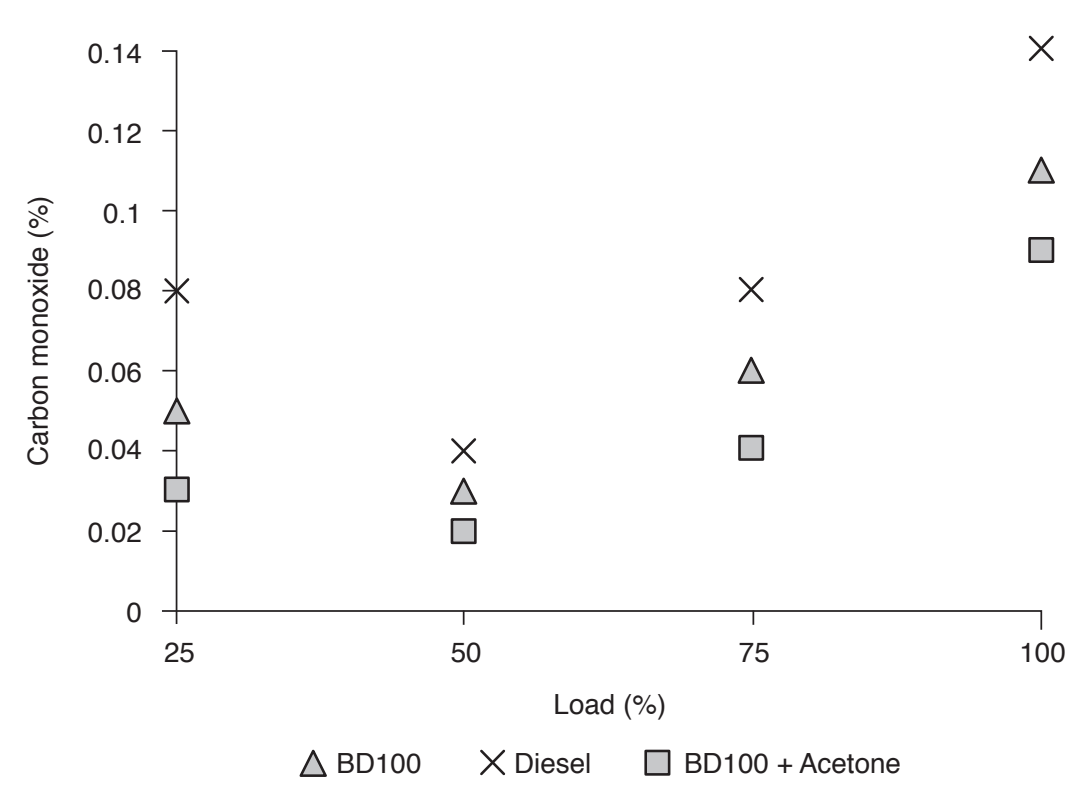

Figure 1. Variation of carbon monoxide (CO) with load.

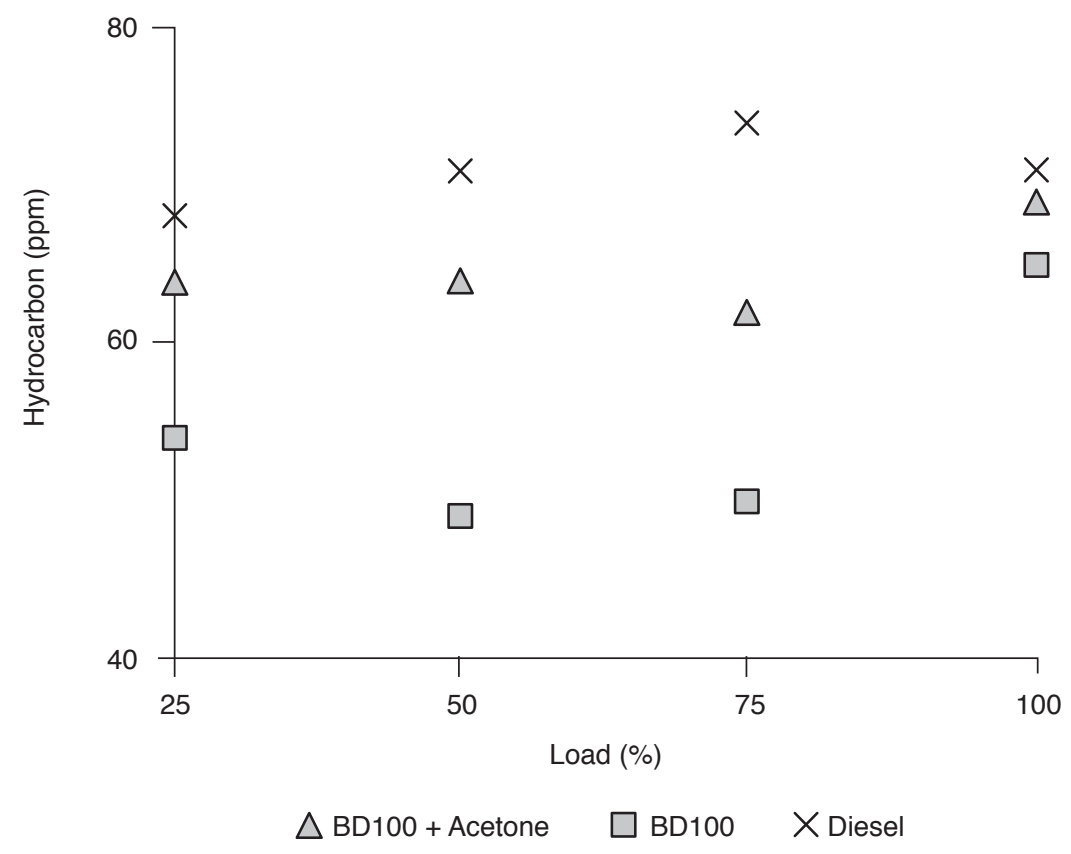

Figure 2. Variation of hydrocarbon (HC) with load.

\section{Oxides of Nitrogen}

The variation of the $\mathrm{NO}_{x}$ emissions with load changes for tested fuels is shown in Figure 3. $\mathrm{NO}_{x}$ emission increases with a load for all the tested fuels. At the higher load, the combustion temperature increases resulting in a higher $\mathrm{NO}_{x}$ emission. $\mathrm{NO}_{x}$ emission reduces with increase in the acetone content. By adding acetone to palm biodiesel resulted in a significant reduction in $\mathrm{NO}_{x}$ emissions, at all loads when compared to neat palm biodiesel.
The lower $\mathrm{NO}_{\mathrm{x}}$ emission is attributable to the lower volatility of acetone-biodiesel mixture (Schroder et al., 2013; Yuvarajan et al., 2017). $\mathrm{NO}_{\mathrm{x}}$ emissions for BD100, BD100 + Acetone and Diesel are 1415, 1355 and 1035 ppm respectively at peak load conditions.

\section{Smoke Opacity}

The variation of the smoke emissions with load changes for tested fuels is shown in Figure 4. Smoke emission increases with load for all the tested fuels. 


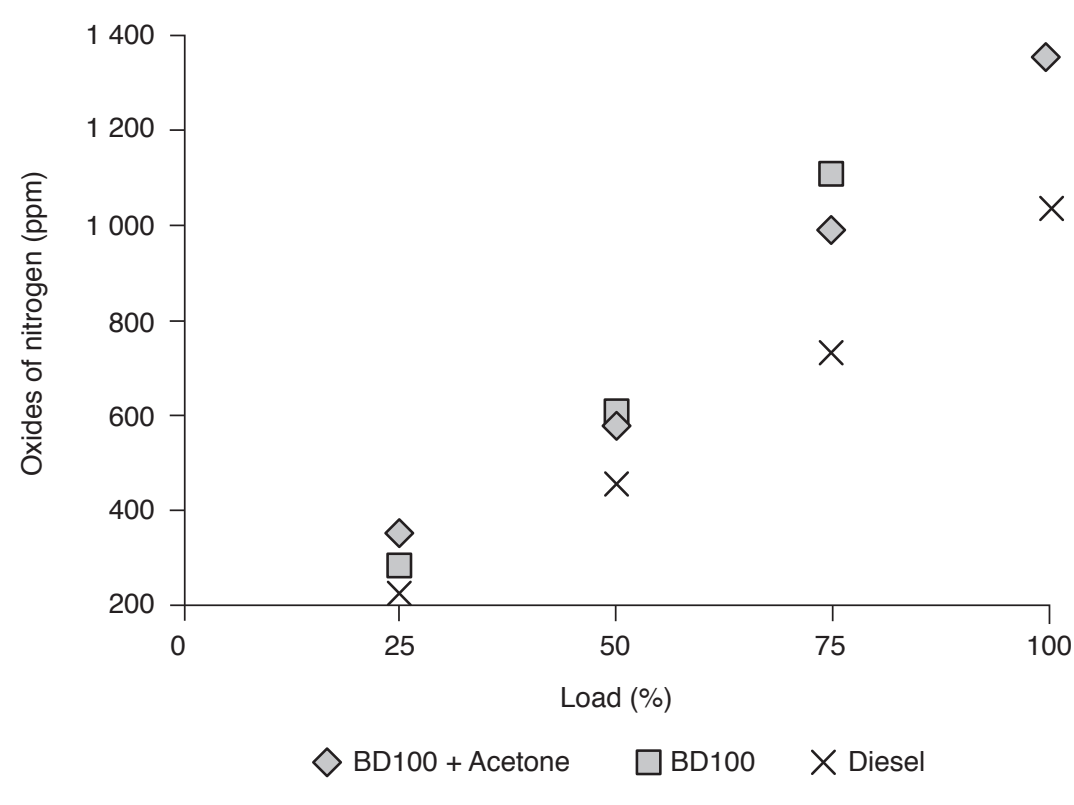

Figure 3. Variation of nitrogen oxides $\left(\mathrm{NO}_{\mathrm{X}}\right)$ with load.

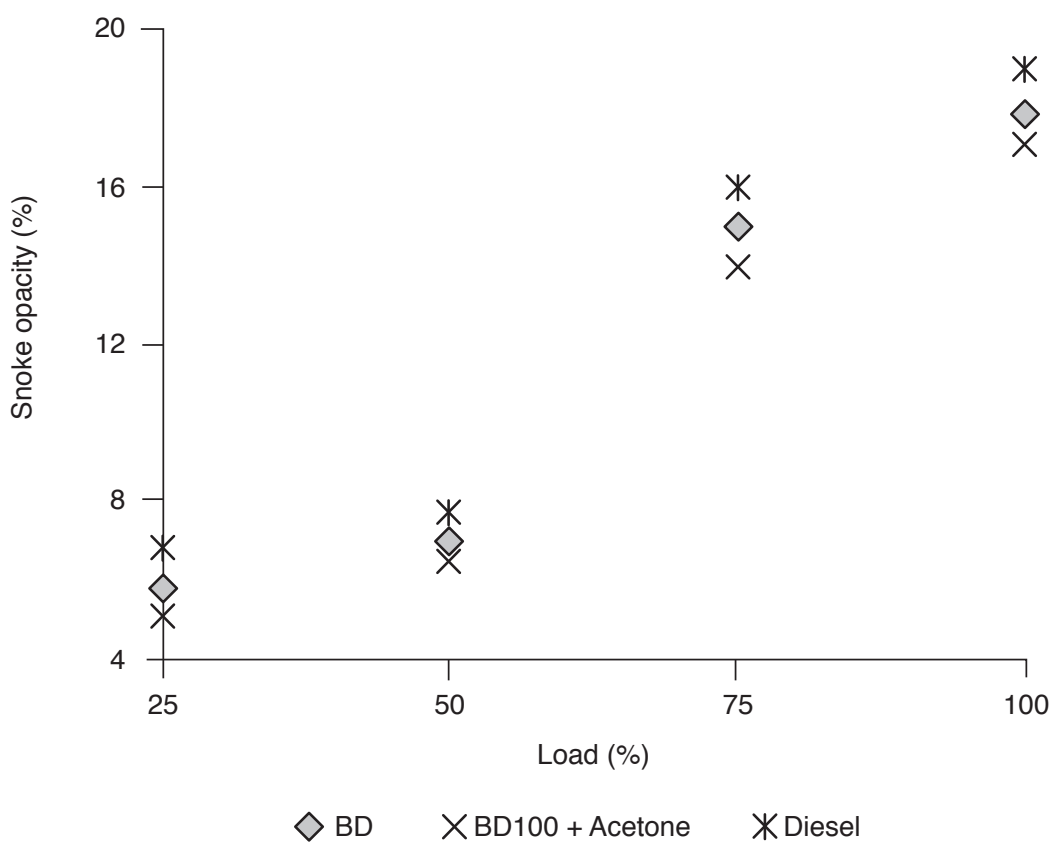

Figure 4. Variation of smoke emissions with load.

At the higher load, the combustion temperature increases resulting in a higher smoke emission (Yuvarajan et al., 2017). Smoke emission reduces with increase in the acetone content. By adding acetone to palm biodiesel resulted in a significant reduction in smoke emissions, at all loads when compared to neat palm biodiesel. The oxygen atoms present in acetone gets bonded during the phase of combustion and lowers the formation of soot (Schroder et al., 2013). Smoke emissions from BD100, BD100 + Acetone and Diesel are 1415, 1355 and 1035 ppm respectively at peak load conditions. A similar trend of reduction in smoke emissions was observed in many studies (Aydin and Ogut, 2017; Kim and Choi, 2010).

\section{CONCLUSION}

The following conclusions can be made from this work: (a) it is experimentally feasible to develop the dual-fuel system using acetone-biodiesel, (b) CO 
emissions were found to be lower for biodiesel and biodiesel-acetone mode than neat diesel at all loads. Further, $\mathrm{CO}$ emission levels were lower in biodieselacetone mode than neat biodiesel operation, (c) HC emissions in biodiesel and biodiesel-acetone mode was lower than diesel at all loads. HC emissions in biodiesel-acetone mode were found to be lower than neat biodiesel at all loads, (d) $\mathrm{NO}_{\mathrm{x}}$ emission was higher for palm biodiesel and palm biodieselacetone dual fueling mode than diesel at all loads. However, $\mathrm{NO}_{\mathrm{x}}$ emission for palm biodiesel-acetone dual fueling mode was lower than neat biodiesel. (e) Smoke emissions from neat palm biodiesel and palm biodiesel-acetone mode were lower than neat diesel in all conditions. Smoke emissions decreased at palm biodiesel-acetone dual-fuel mode owing to improvement in the combustion.

\section{REFERENCES}

AYDIN, F and OGUT, H (2017). Effects of using ethanol-bio-diesel-diesel fuel in single cylinder diesel engine to engine performance and emissions. Renew Energy, 103: 688-694.

DEVARAJAN, Y; JAYABAL, R; KUMAR, RAGUPATHY, D and VENU, H (2016). Emissions analysis on second generation bio-diesel. Frontiers of Environmental Science Eng., 11(1).

DEVARAJAN, Y; MUNUSWAMY, D B; MAHALINGAM, A and NAGAPPAN, B (2017a). Performance, combustion, and emission analysis of neat palm oil bio-diesel and higher alcohol blends in a diesel engine. Energy Fuel. DOI:10.1021/acs. energyfuels.7b02939.

DEVARAJAN, Y; MUNUSWAMY, D B and MAHALINGAM, A (2017b). Performance, combustion and emission analysis on the effect of ferrofluid on neat bio-diesel. Process Safety Environ Protect., 111: 283-291.
KIM, H and CHOI, B (2010). The effect of bio-diesel and bioethanol blended diesel fuel on nanoparticles and exhaust emissions from CRDI diesel engine. Renew Energy, 35(1): 157-163.

RADHAKRISHNAN, S (2017). Emissions analysis on diesel engine fueled with palm oil bio-diesel and pentanol blends. J. Oil Palm Res. Vol. 29(3): 380 -386. DOI:10.21894/jopr.2017.2903.11.

SANTHOSHAM, A and AGHALAYAM, P (2016). Understanding $\mathrm{NO}_{x}$ emissions in diesel and biodiesel based engines. RSC Advances, 6(64): 59513 59526.

SCHRODER, O; BUNGER, J; MUNACK, A; KNOTHE, G and KRAHL, J (2013). Exhaust emissions and mutagenic effects of diesel fuel, biodiesel and bio-diesel blends. Fuel, 103: 414-420.

YILMAZ, N; ILERI, E and ATMANLI, A (2016). Performance of bio-diesel/higher alcohols blends in a diesel engine. I. J. Energ Res., 40(8): 1134-1143.

YUVARAJAN, D and RAMANAN, M V (2016a). Effect of magnetite ferrofluid on the performance and emissions characteristics of diesel engine using methyl esters of mustard oil. Arabian J.Sci. Engg., 41(5): 2023 - 2030

YUVARAJAN, D and VENKATA RAMANAN, M (2016b). Experimental analysis on neat mustard oil methyl ester subjected to ultrasonication and microwave irradiation in four stroke single cylinder diesel engine. J.Mech. Sci.Technol., 30(1): 437-446.

YUVARAJAN, D; DINESH BABU, M; BEEMKUMAR, N and AMITH KISHORE, P (2017). Experimental investigation on the influence of titanium dioxide nanofluid on emission pattern of bio-diesel in a diesel engine. Atmos Pollut Res., DOI:10.1016/j.apr.2017.06.003. 